Global Conferences Series:

Sciences and Technology (GCSST), Volume 5, 2020

Seminar Nasional I Baristand Industri Padang (Semnas I BIPD)

DOI:https://doi.org/10.32698/GCS-SNIIBIP D3435

\title{
Organik waste processing with black soldier fly larvae (Hermetia illucens)
}

\section{Pengolahan sampah organik dengan larva black soldier fly (Hermetia illucens)}

\author{
Sri Mutiar ${ }^{1}$, Yulhendri ${ }^{2}$ \\ ${ }^{1}$ Program Studi Teknologi Industri Pertanian, Universitas Dharma Andalas, Padang, Indonesia \\ ${ }^{2}$ Lembaga Pemerdayaan Masyarakat (LPM), Sumatera Barat, Indonesia \\ E-mail: srimutiar@unidha.ac.id
}

\begin{abstract}
Organic waste produced by the community has the potential to manage the organic. The purpose of this study was to obtain benefits from waste processing in the form of organic fertilizers that are safe for the environment and contain nutrients that meet the standards as compost and BSF larvae. The method used is to utilize the larvae of the Black Soldier Fly (BSF) type as an organism to decompose organic waste. The results of the study produced two products, namely BSF larvae in the form of pupae which can be used as feed and the decomposition residue as compost. BSF larvae can be used as feed that enough nutrients in the form of protein, fat and minerals. The results of the compost analysis showed that the results met the SNI 19-70302004 standards as organic fertilizers with the content of $N: 1.04 \%, P: 2.25 \%, K: 1.55$ and $C / N 14.14 \%$.
\end{abstract}

Keywords: organik waste; compost; black soldier fly larvae

\begin{abstract}
Abstrak:Sampah organik yang dihasilkan masyarakat menjadi potensi untuk mengelola sampah organik. Tujuan studi ini adalah untuk mendapatkan manfaat dari pengolahan sampah berupa pupuk organik yang aman terhadap lingkungan dan memiliki kandungan unsur hara yang memenuhi standar sebagai pupuk kompos serta larva BSF. Metode yang digunakan adalah memanfaatkan larva dari lalat jenis Black Soldier Fly (BSF) sebagai organisme pengurai sampah organik. Hasil studi menghasilkan dua produk yaitu larva BSF dalam bentuk pupa yang dapat digunakan sebagai pakan dan residu hasil penguraian sebagai kompos. Larva BSF dapat dijadikan sebagai pakan yang memenuhi nutrient berupa protein, lemak dan mineral. Hasil analisa pupuk kompos menunjukkan hasil memenuhi standar SNI 19-7030-2004 sebagai pupuk organik dengan kandungan N : 1,04\% , P :2,25\%, K : 1,55 dan C/N 14,14\%.
\end{abstract}

Kata kunci: sampah organic; kompos; larva Black Soldier Fly

\section{PENDAHULUAN}

Sampah organik merupakan bahan-bahan yang berasal dari tumbuhan atau hewan yang diambil dari alam. Sampah organik dihasilkan pada kegiatan pertanian dan peternakan serta sebagian besar sampah rumah tangga merupakan bahan organik, misalnya sampah dari dapur, sisa tepung, sayuran, kulit buah, dan daun. Sampah ini mudah diuraikan dalam proses alami. Menurut Monita et al., (2017) sampah organik adalah jenis sampah yang tersusun oleh senyawa organik dan bersifat degradable. Secara alami dapat diuraikan oleh jasad hidup khususnya mikroorganisme.

Menurut Undang-undang Nomor 18 Tahun 2008, sampah adalah sisa kegiatan sehari-hari manusia dan/atau proses alam yang berbentuk padat, adapun pengelolaan sampah merupakan kegiatan yang sistematis, menyeluruh, dan berkesinambungan yang meliputi pengurangan dan penanganan sampah. Menurut (Diener et al., 2011), sampah organik yang jumlahnya bisa mencapai $80 \%$ dari total sampah, biasanya hanya dilihat sebagai barang sisa tanpa nilai ekonomi sama sekali. Data ini menunjukkan sampah organik berpotensi untuk dikelola menjadi kompos. Berbagai metode pengomposan telah banyak dikembangkan dan diaplikasikan di Indonesia mulai dari teknologi sederhana sampai yang menggunakan peralatan canggih. Salah satu alternative yang dapat digunakan adalah pengolahan sampah enggan

Copyright (C) 2020, the Authors. Published by Redwhite Press. 
menggunakan larva dari lalat jenis Black Soldier Fly (Hermetia illucens). Larva BSF mampu mengkonsumsi sampah organik dalam jumlah besar lebih cepat dan lebih efisien. Hal ini disebabkan oleh enzim pencernaannya yang lebih aktif yang terdaat pada bagian mulut larva BSF (Kim et al., 2010). Menurut Diener et al., (2011) larva BSF mampu mampu mereduksi sampah organik $66-78,9 \%$ dan $85 \%$ berat basah (Dortmans, 2015).

Berdasarkan hal tersebut diatas, larva dari lalat jenis Black Soldier Fly (Hermetia illucens) dapat menjadi terobosan untuk mendapatkan manfaat berupa larva BSF dan pupuk organik/kompos yang aman lingkungan dan menghasilkan kandungan hara yang optimal. Hasil penguraian sampah organik oleh larva dari lalat jenis BSF dapatmenjadi kompos yang kaya akan nutrisi yang dibutuhkan oleh tumbuhan. Proses pengelolaan sampah organik menggunakan larva BSF ini memberikan dua manfaat sekaligus yaitu larva dari lalat BSF atau disebut maggot dan pupuk kompos.

\section{METODE}

\section{Alat dan Bahan}

Peralatan yang digunakan antara lain wadah tempat pembuatan media berupa beberapa ember plastik ukuran $\varnothing 70 \mathrm{~cm}$ sebagai wadah kultur BSF, sendok pengaduk dan timbangan analitik. Bahan yang digunakan adalah Limbah sayur/ buah-buahan dari pasar di kelurahan Jawi-Jawi II, Kec. Pariaman Tengah, Kota Pariaman, dedak, ampas tahu dan daun pisang untuk penutup media. Bahan-bahan kimia untuk analisis kandungan nutrien di laboratorium.

\section{Pelaksanaan Penelitian}

Persiapan media tumbuh larva diawali dengan mengambil sampah organik dari pasar kelurahan JawiJawi II, Kec. Pariaman Tengah, Kota Pariaman. Selanjutnya dilakukan pemotongan dengan ukuran $\pm 5 \mathrm{~cm}$ untuk menyeragamkan ukuran. sampah organik yang digunakan adalah bagian yang masih segar untuk menghindari kontaminasi dari lalat lain. dedak dan ampas tahu dengan perbandingan 3:1 diaduk sampai merata. Selanjutnya di timbang $20 \mathrm{~kg}$ sampah organik yang telah dikecilkan ukuranya dan dicampurkan dengan campuran ampas tahu dan dedak. Setelah bahan tercampur, bahan dimasukkan kedalam wadah untuk biakan BSF dan ditutup dengan daun pisang. Media dan wadah yang telah ditutup selanjutnya diletakkan di tempat yang sejuk dekat area tanaman/pohon selama 1 minggu. Setelah satu minggu akan terlihat larva muda. selanjutnya ditambahkan sampah organik $1 / 3$ bagian $(6-7 \mathrm{~kg})$. setelah 2 minggu larva sudah memasuki fase prepupa yang di sebut maggot. Maggot ini bisa di panen dan digunakan sebagai pakan ternak. (Monita et al., 2017) maggota dapat di panen $40-50 \%$ pada fase prepupa. 50\% selanjutnya dipanen pada fase pupa. Residu yang dihasildari proses dekomposisi larva dimasukan kedalah wadah karung plastik dan di biarkan selama 1minggu untuk selanjutnya disebut sebagai kompos. Analisis pupuk kompos dilakukan mengacu kepada (BSN, 2012) SNI 2803-2012.

\section{HASIL DAN PEMBAHASAN}

Kompos yang diperoleh dari mengunakan sampah organik dengan larva BSF berwarna coklat kehitaman dan berbau seperti tanah. Pemanfaatan larva BSF sebagai agen pengompos sampah organik dihasilkan berupa pupa BSF sebagai pakan dan residu sebagai pupuk kompos ini dapat dilihat pada Gambar 3. Teknologi pengomposan sampah sangat beragam. Menurut (Ekawandani and Alvianingsih, 2018) menyatakan pengomposan dapat terjadi secara aerob maupun anaerob, dengan atau tanpa aktivator pengomposan. Proses dekomposisi akan berlangsung optimal jika aktivator merupakan bahan yang terdiri atas enzim, asam humat, dan mikroorganisme yang berfungsi untuk mempercepat proses pengomposan.

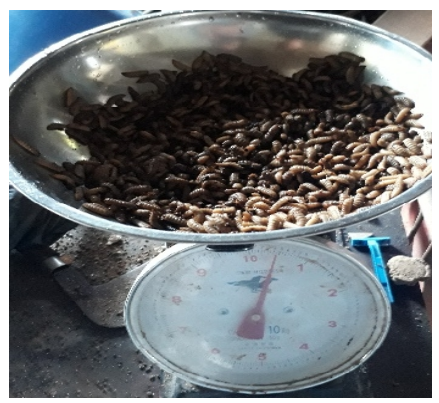

Gambar 1. Pre pupa dapat dipanen setelah 2 minggu 


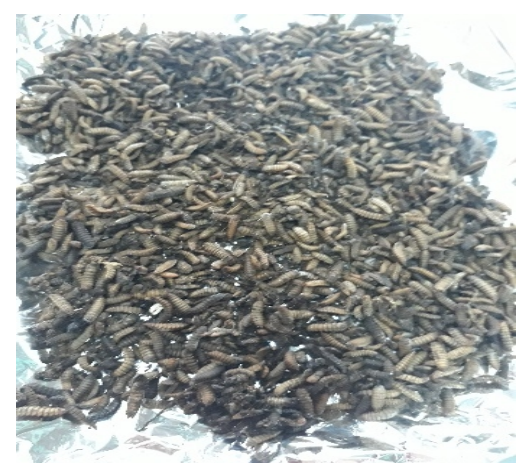

Gambar 2. Pupa dari BSF yang di panen setelah 21 hari

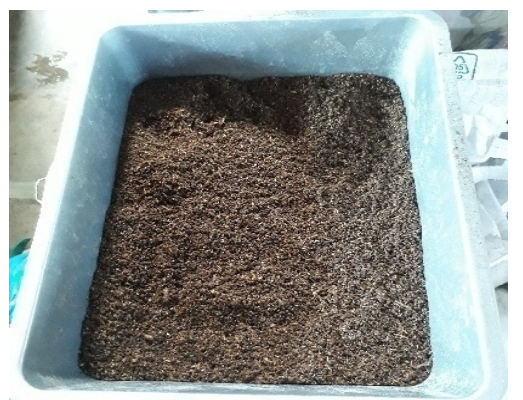

Gambar 3. Pupuk kompospada pengolahan sampah organik dengan larva BSF

Larva BSF pada fase prepupa berwarna coklat kekuningan dan coklat muda (Gambar 1). pergerakan larva pada fase ini sangat aktif. Fase ini berlangsung selama 6 hari selanjutnya akan masuk kedalam fase pupa. Menurut Monita et al., (2017) sebagai agen dalam biokonversi bagian sampah oganik, fase larva BSF dapat dijadikan sebagai acuan karena sebagian besar fase prepupa hidupnya berperan sebagai decomposer. Dengan demikian, larva berpotensi mampu mengkonversi limbah/sampah organik dalam jumlah besar menjadi biomassa mengandung unsur hara. Selanjutnya fase prepupa bermetamofosis menjadi fase pupa. Fase ini dicirikan dengan adanya perubahan warna tubuh yaitu coklat gelap sampai hitam (Gambar 2). Selain itu, pergerakan tubuh prepupa yang melambat berangsur-angsur tidak bergerak (pasif) dengan tekstur kulit pupa lebih keras, dan bobot tubuh lebih ringan. Menurut (Diener et al., 2011) fase pupa adalah fase di mana larva BSF tidak makan lagi dan bermigrasi dari sumber makanan mencari tempat kering dan tempat terlindungi untuk memasuki tahap penetas. Hal ini menjadi acuan dalam proses pengomposan sampah organik oleh larva BSF.

Pemanfaatan BSF untuk mengurai sampah menjadi pupuk kompos dirasa cukup potensial. Hal ini sesuai dengan pendapat (Sipayung, 2015) BSF merupakan lalat yang berkembang baik pada daerah tropis dan dapat mengurai materi organik serta mampu berkembangbiak sebanyak dengan sangat cepat dan jumlah yang banyak. (Holmes et al., 2012) BSF betina dewasa menghasilkan telur antara 320-620 pada masa kopulasi kurang dari 2. Sehingga penggunaan larva BSF sangat cocok untuk mengurai sampah organik menjadi pupuk kompos. Menurut Diener et al., (2011) larva BSF mampu mendegradasi sampai $80 \%$ dari jumlah sampah organik yang diberikan. Dengan demikian penggunaan larba BSF ini dapat menjadi salah satu teknologi untuk pengelolaan sampah organik, terutama sampah organik dapat diatasi dengan volume yang lebih besar dengan menghasilkan produk berupa larva BSF (maggot) dan pupuk kompos. Berikut Tabel 1, menampilkan hasil analisa larva BSF setelah dipanen.

Tabel 1. Data hasil analisa larva BSF (maggot)

\begin{tabular}{llc}
\hline & & Maggot(\%) \\
\cline { 2 - 3 } Parameter & Larva $\left(\mathrm{BB}^{*}\right)$ & Larva $\left(\mathrm{BK}^{* *}\right)$ \\
Protein & 19,90 & 51,20 \\
Air & 63 & 12,26 \\
Abu & 3,4 & 7,3 \\
Lemak & 6,7 & 11.44 \\
\hline Sumber: (Mutiar, 2018) & \\
Keterangan: *dianalisa berdasarkan berat segar & \\
& $* *$ dianalisa berdasarkan berat kering &
\end{tabular}


Hasil analisa maggot ini menunjukkan bahwa maggot ini dapat dijadikan sebagai pakan ternak, terutama pada ternak ikan. Kandungan nutrien dari larva ini yang dihasilkan mampu memenuhi kebutuhan nutrien pada pakan ikan. Kandungan nutrie dari maggot segar, berdasarkan hasil uji mengandung protein : 19,90\%, kadar air : 63\%, kadar abu : 3,4\% dan lemak 6.7\% Sementara maggot kering nilai protein : 51,20\% , kadar air : 12,26\% : mineralnya 7,3\% dan lemak 11,44\%. Jika ditinjaua dari kebutuhan protein pakan lele, nilai ini sudah memenuhi kebutuhan pakan tersebut. (Monita et al., 2017) menyatakan terdapat beberapa hasil penelitian tentang kandungan nutrisi larva BSF yang digunakan sebagai pakan diantaranya (Nguyen et al., (2015) ; Fahmi, (2015) ; Diener et al., (2011)dan Rachmawati et al., (2010).

Berdasarkan aturan dalam Permentan Nomor28/Permentan/SR. 130/5/2009, menyatakan bahwa bahwa pupuk organik adalah pupuk yang sebagian besar atau seluruhnya terdiri dari bahan organik yang berasal dari tanaman dan hewan yang telah mengalami proses rekayasa, dapat berbentuk padat atau cair yang digunakan untuk mensuplai bahan organik, memperbaiki sifat fisik, kimia, dan biologi tanah. BSF merupakan lalat tropis yang mempunyai kemampuan mengurai material organik dengan sangat baik karena kemampuan mengekstrak sampak organik sebagai sumber makannya (Holmes et al., 2012) dan dapat digunakan sebagai agen pengurai limbah organik (Rachmawati et al., 2010). Tabel 2 berikut adalah hasil analisa pupuk kompospada pengolahan sampah organik dengan larva BSF.

Tabel 2. Hasil uji parameter pupuk kompos menggunakan larva BSF

\begin{tabular}{lllll}
\hline Parameter & Satuan & SNI 19-7030-2004 & Hasil analisa & Keterangan \\
\hline Nitrogen total & $\%$ & Min. 0,40 & 1,04 & Memenuhi Standar \\
Phospor (P2O5) & $\%$ & Min. 0,10 & 2,25 & Memenuhi Standar \\
Kalium (K2O) & $\%$ & Min. 0,20 & 1,55 & Memenuhi Standar \\
C-Organik & $\%$ & $9,8-32$ & 14,72 & Memenuhi Standar \\
C/N & - & Min. 10 & 14,14 & Memenuhi Standar \\
pH & - & $6,80-7,49$ & 7,73 & - \\
\hline
\end{tabular}

Menurut SNI 19-7030-2004 (BSN, 2004) C/N rasio untuk pupuk organik adalah 10-20 dengan kadar C-organik 9,8-32\%. Berdasarkan standar tersebut, maka dinyatakan residu hasil dekomposisi larva BSF cocok untuk dijadikan sebagai pupuk organik. Menurut (Nursaid et al., 2017) Bahan organik yang mengandung unsur $\mathrm{C}$ tinggi akan mengahasilkan nilai $\mathrm{C} / \mathrm{N}$ rasio yang tinggi demikian sebaliknya. Kandungan C-organik pupuk kompos menggunakan larva BSF adalah 14,72\%. Hal ini menjadi factor pendukung larva BSF dapat mengurai sampah organik. Menurut (Rachmawati et al., 2010) kandungan Corganik akan dimanfaatkan sebagai sumber energy dalam pengomposan sedangkan Kandungan $\mathrm{N}$-total akan dimanfaatkan untuk mensitesis protein. Hal ini diperkirakan dapat mempengaruhi kecepatan proses pendegradasian sampah organik, karena adanya unsur hara yang terdapat dalam sampah organik sebagai media pertumbuhan larva BSF. Berdasarkan pengukuran $\mathrm{pH}$ pupuk kompos yang dilakukan, $\mathrm{pH}$ pupuk kompos berada pada kondisi netrat dengan nilai 7,73.

\section{SIMPULAN}

Larva BSF dapat dimanfaatkan untuk mengurai sampah organik sehingga menghasilkan dua produk yaitu larva BSF dalam bentuk pupa yang dapat digunakan sebagai pakan dan residu hasil penguraian sebagai kompos. Larva BSF mampu mengurai sampah organik dan dapat dijadikan sebagai pakan yang memenuhi nutrient berupa Protein, lemak dan mineral.Hasil analisa pupuk kompos menunjukkan hasil memenuhi standar SNI 19-7030-2004 sebagai pupuk organik dengan kandungan $\mathrm{N}: 1,04 \%, \mathrm{P}: 2,25 \%, \mathrm{~K}: 1,55$ dan $\mathrm{C} / \mathrm{N}$ $14,14 \%$.

\section{UCAPAN TERIMA KASIH}

Lembaga Pengelolaan Dana Pendidikan (LPDP) yang telah membiayai penelitian ini melalui Beasiswa BUDI-DN. Badan Penelitian dan Pengembangan Provinsi Sumatera Barat (Balitbang) yang telah memberikan penghargaan dalam Lomba Karya Inovasi Iptek Tahun 2018. LPM Kelurahan Jawi-Jawi II, Kec. Pariaman Tengah, Kota Pariaman sebagai lokasi penelitian. Balai Riset dan Standarisasi Industri padang yang telah membantu dalam pengujian sampel. 


\section{REFERENSI}

BSN, 2012. Standar Nasional Indonesia SNI 2803:2012 tentang Pupuk NPK padat. Badan Standardisasi Nasional.

BSN, 2004. Standar Nasional Indonesia SNI 19-7030-2004 tentang spesifikasi kompos dari sampah organik domestik. Badan Standardisasi Nasional.

Diener, S., Zurbrügg, C., Gutiérrez, F.R., Nguyen, D.H., Morel, A., Koottatep, T., Tockner, K., 2011. Black soldier fly larvae for organic waste treatment-prospects and constraints. Proc. WasteSafe 2011-2nd Int. Conf. Solid Waste Manag. Dev. 52-59.

Dortmans, B., 2015. Valorisation of organic waste-Effect of the feeding regime on process parameters in a continuous black soldier fly larvae composting system.

Ekawandani, N., Alvianingsih, 2018. Efektifitas kompos daun menggunakan EM4 dan kotoran sapi (preprint). INA-Rxiv. https://doi.org/10.31227/osf.io/pyqaj

Fahmi, M.R., 2015. Optimalisasi proses biokonversi dengan menggunakan mini-larva Hermetia illucens untuk memenuhi kebutuhan pakan ikan. Prosididng Semin. Nas. Masy Biodiv Indon 1, 139-144.

Holmes, L.A., Vanlaerhoven, S.L., Tomberlin, J.K., 2012. Holmes, L.A., Vanlaerhoven, S.L., Tomberlin, J.K. 2012. Relative humidity effects on the life history of Hermetia illucens. Diptera Strat. Environ. Entomol. 41, 971-978.

Kim, W., Bae, S., Park, H., Park, K., Lee, S., Choi, Y., Han, S., Koh, Y., 2010. The larval age and mouth morphology of the black soldier fly, Hermetia illucens. Diptera Strat. Int J Indust Entomol 21, 185187.

Monita, L., Sutjahjo, H.S., Amin, A.A., Fahmi, M.R., 2017. Municipal organic waste recycling using black soldier fly larvae (Hermetia illucens). J. Pengelolaan Sumberd. Alam Dan Lingkung. Vol. 7, 227-234.

Mutiar, S., 2018. Subsitusi pakan ternak lele dengan pengembangbiakan maggot dari black soldier fly (BSF) sebagai pakan murah. Lomba Karya Inovasi Iptek (Kategori Teknologi Menengah).

Nguyen, T.T.X., Tomberlin, J.K., Vanlaerhoven, S., 2015. Ability of black soldier fly (Diptera: Stratiomyidae) larvae to recycle food waste. Env. Entomol 44, 406-410.

Nursaid, A.A., Yuriandala, Y., Maziya, F.B., 2017. Analisis laju penguraian dan hasil kompos pada pengolahan sampah buah dengan larva Black Soldier Fly (Hermetia Illucens) 9.

Rachmawati, Buchori, D., Hidayat, P., Saurin, H.E.M., Fahmi, N.R., 2010. Perkembangan dan kandungan nutrisi Larva Hermetia illucens (Linnaeus). J. Entomol. Indones. 7, 28-41.

Sipayung, P.Y.E., 2015. Pemanfaatan larva black soldier fly (Hermetiaillucens) sebagai salah satu teknologi reduksi sampah di daerah perkotaan. Departement Environ. Eng. Fac. Civ. Eng. Plan. Inst. Technol. Sepuluh Nop. Surabaya. 